\title{
'Joy':
}

\section{Memorialisation and the Limits of Tolerance}

RAELENE FRANCES AND JULIE KIMBER

Dublic art plays a contested role in urban planning and

1 development. The form of such art can be 'institutional', individual or participatory. In seeking to 'beautify' urban landscapes, institutional public art has been criticised for its role in the historical reinvention of urban space. Commissioned public art, designed to promote a unified, ordered conception of a 'community', has been accused of being 'complicit in obscuring the inequitable roots and consequences of urbanisation'. ${ }^{1}$ While such concerns revolve around the representational aspects of public art, and hence illuminate the gaze of 'the outsider more than a participant', ${ }^{2}$ the exclusive nature of much public art is difficult to ignore.

Phillips' discussion of the 'machinery of public art' highlights the constraints, vested interests and ultimately the 'blandness' and 'mediocrity' ${ }^{3}$ of much commissioned public art, which serves to 
project 'selective versions of history, or myths of harmony'. However, as Hall's deconstruction of the statue Forward in the 'postindustrial' city of Birmingham demonstrated, this is not necessarily clear-cut. ${ }^{5}$ As Burk has cautioned, blanket assumptions on the role of public art can distort the ways in which 'art actually functions in an environment'. ${ }^{6}$ It is this examination of the 'multiple sites of meaning', with a specific focus on 'audience', or resident reaction to public art, which forms the basis of this study.

Seldom without controversy, at least in its formative stages, public art's ability to arouse, limit and repress memory corresponds with its palatability and purpose. Australian towns and cities are peppered with memorials to the fallen, the pioneers, the pious and the self-promoting. They exist, as Hamilton has argued, to remember or to be remembered. The most numerous of these are memorials in the service of nation building, especially prominent are the monuments to Australia's role in foreign wars. ${ }^{7}$ More recently, monuments, sculptures and public art generally have begun to reflect broader and more eclectic characterisations. There are, for example, a growing number of 'counter-hegemonic' monuments in Australia, including memorials to Indigenous Australians, ${ }^{8}$ women and workers.

The numerous workers' memorials commemorating heroic male figures include: coalminers in Collie, Western Australia, in Charlestown, New South Wales and in Korumburra, Victoria; truck drivers in Grafton and Tarcutta, New South Wales; timber workers in Manjimup, Western Australia and in Eden and Lismore, New South Wales; and cane cutters in Innisfail, Queensland. Additionally, the lead, silver and zinc miners are commemorated in the industrial and remote city of Broken Hill in far west New South Wales. ${ }^{9}$

Many such memorials nourish a masculinist, albeit working-class vision of Australia's nation building efforts. Of memorials to women workers most 'identify them in the traditional roles of service (for example teachers and nurses) or in sedentary occupations'. Other memorials to women are to 'the exceptional' - those who 'stand in a no-man's land between the heroic men immortalised in stone and the ordinary women who are not'. ${ }^{10}$ There are, however, exceptions to these stereotypes. 


\section{REMOVING THE 'CARNIVAL MASK'}

For eighteen months in 1995-7, the statue of 'Joy' stood quietly smoking against her red door frame at the corner of Yurong and Stanley Streets in East Sydney. She was unusual in many respects. 'Joy' is neither male, nor heroic in conventional terms, representing, as she does, a street sex worker waiting for custom. She is also unusual in that she was conceived and constructed as an individual work of public art. She was not commissioned by an organisation, such as a trade union, as is the case in most other such structures. As such Joy fits in more closely with the more recent tradition of 'new genre' public art. ${ }^{11}$ This, as Hall has noted, 'seeks to disrupt prevailing conceptions of the city, highlighting contradictions, processes of uneven development and the marginalisation and exclusion of certain groups within the city, such as the homeless and women. ${ }^{12}$

The statue as it finally took shape also proved eerily peculiar. Unlike other monuments depicting stereotypical figures, Joy bore a remarkable resemblance to a real person. According to the sculptor, Loui Fraser, this was unintentional on her part. On the very day that she was shaping Joy's striking facial features, a young woman whom she had never seen but whose face bore a remarkable similarity to these very features was dying in a hospital in a New South Wales country town.

After the funeral, the young woman's mother, who had been at her daughter's bedside when she died, returned to her Darlinghurst home to find the newly-erected statue of Joy in the street outside her house. She immediately noticed the resemblance and, overcome with emotion, took a large hammer to the sculpture. She did considerable damage before being carted off in a police wagon. When Loui later spoke to the mother about her actions, she discovered that the woman's daughter, Lisa, had been a Sydney sex worker for many years. In fact, she'd been introduced to the occupation by her mother, who was herself a brothel keeper of longstanding. Joy was too vivid a reminder of the young woman's life, her early death a result of illhealth following years of heroin addiction. ${ }^{13}$

Loui Fraser had originally intended to construct a statue entitled 'One Who Waits' in the street in East Sydney where she owned a house. She later changed the name to 'Joy', 'for its ambiguity'. ${ }^{14}$ While looking out of the window of her house one morning, she had 


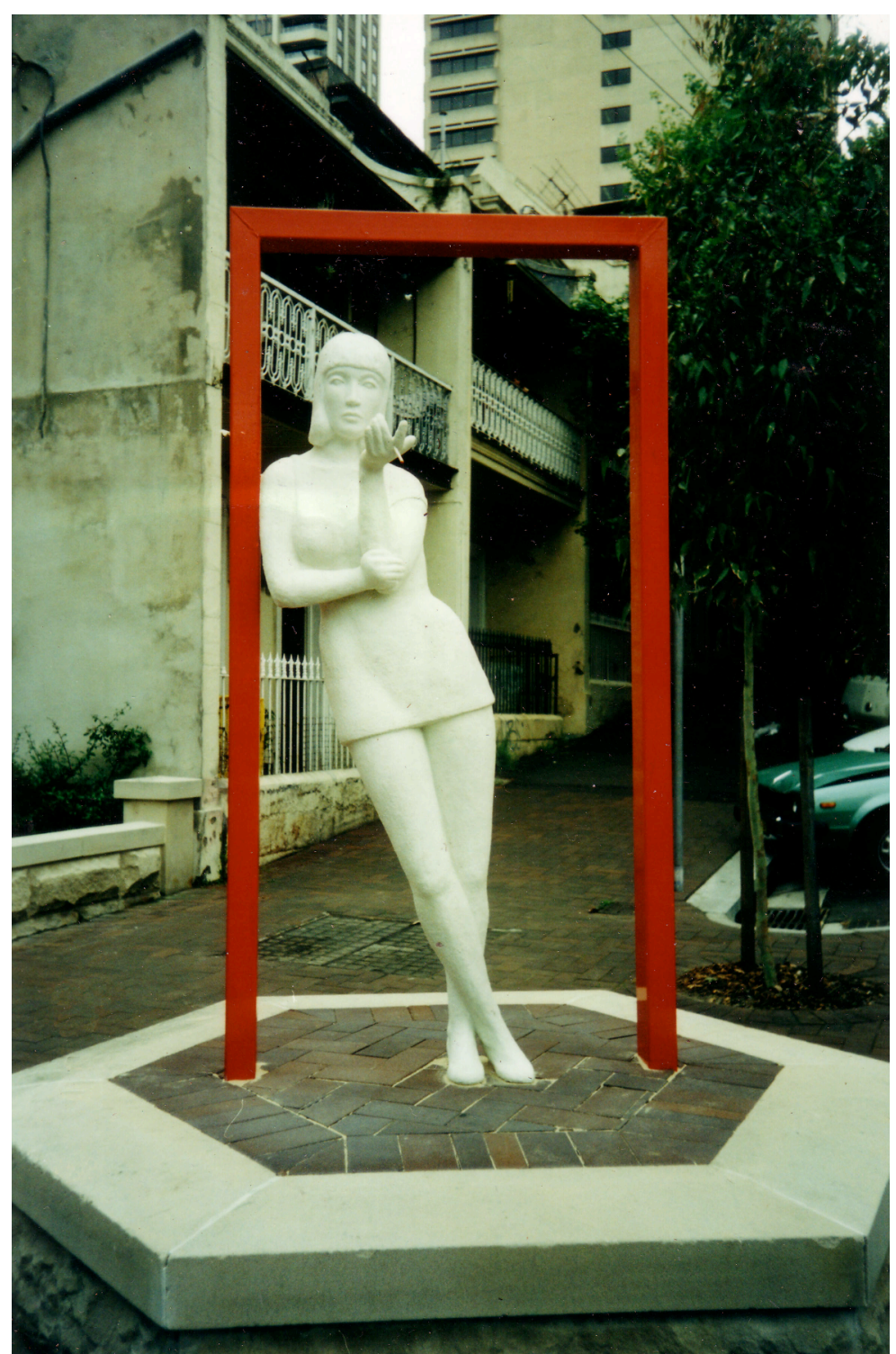

'Joy' in situ on the corner of Stanley and Yurong Streets, East Sydney, Loui Fraser sculptor (Photographer Loui Fraser)

noticed a hexagonal sandstone plinth at the edge of the park where Stanley and Yurong Streets meet. As she relates, 'As soon as I saw it I thought "well, I know what I would put there if I had a chance."'15 'I knew straight away what type of sculpture would be appropriate for the site, given the prominence of street workers in East Sydney. ${ }^{16}$ Fraser approached South Sydney City Council with the proposal for a figure which looked very similar to the final version, except for the facial features and hairstyle. Her intention was to pay tribute to the 
thousands of women who had historically sold sexual services in the area. As she recalled: 'I believed it was the obvious subject to have at that site, and it was time these women were recognised as part of our society and history, particularly in that part of Sydney. ${ }^{17}$

Although the subject might have been obvious to Fraser, she soon realised that others did not share her view. The proposal provoked considerable controversy on the Council and was eventually approved by only one vote. ${ }^{18}$ Once the larger-than-life cement, marble dust and steel statue took up her position on the street, the controversy broadened. It is these different responses that provide the subject of this article, offering, as they do, a snapshot of latetwentieth century Sydney views on prostitution and history.

Lefebvre's observation of the dialectic of 'reality' and 'reflection' within public space points to the illusive but also the conflictual nature of spatial representation. ${ }^{19}$ As Hall has observed, an 'industrial history... in the context of the postindustrial economy, is both a problematic and a contested terrain from which to narrate new cultural geographies of the city through the media of urban regeneration. ${ }^{20}$ The contested terrain at the heart of this story is the contradictory projections of the past, present and future of the innerurban neighbourhood of East Sydney. Like many industrial cities around the world, Sydney has undergone a major transformation since the 1970s. Capital investment and shifting industrial technologies have altered the landscape and many inner urban areas, once home to strong working-class communities, have undergone uneven processes of gentrification. These processes are equally evident in East Sydney, encompassing the areas of Darlinghurst and Kings Cross. Once famous for its colourful and exciting residential mix, East Sydney was a magnet for diverse visitors, including sailors from the nearby Naval bases. Not surprisingly, East Sydney was also famous for the large number of brothels and streetwalkers soliciting for business. ${ }^{21}$

Over the last couple of decades, however, changes to laws relating to prostitution, urban redevelopment and inflated house prices have altered the demographic mix of the area. It is in this context that public reactions to the statue of 'Joy' reflect the shifting identities of place. Unlike the 'carnival mask' creating 'the impression of affluence, vibrancy, conviviality, change and regeneration', ${ }^{22}$ a criticism made of some public art, 'Joy' was a direct link to the history 
and role of prostitution in the area, and uncovers the deeper layers embedded within East Sydney.

In removing the 'carnival mask', 'Joy' brought to the surface diverse beliefs and attitudes about the identity of East Sydney. It is a case study which, in small measure, mirrors the controversy analysed in Leib's study of Monument Avenue in Richmond, Virginia, over 'whose history is represented within the region's public spaces. ${ }^{\prime 23}$ Leib reminds us of Bodnar's suggestion that the 'concept of public memory, how the past is interpreted, commemorated and represented has as much to do with shaping how society understands its present and future as with about the past per se. ${ }^{24}$ The highly political nature of public monuments, sculptures and symbols is examined here through a textual and social analysis of the reactions to 'Joy'. These reactions include physical interactions with the statue - both hostile and otherwise - as well as comment in the media and approaches to the local city council.

\section{THE LIMITS OF TOLERANCE}

The most immediate reaction, as we have seen, was the violent response of Lisa's mother, Wendy. Wendy proved the easiest critic to placate. Loui Fraser declined to press charges against her for the damage done to Joy. She subsequently met with Wendy, who told Fraser the story of her life as a brothel madam. She also related the fate of her daughter, who had tried to give up heroin and prostitution by moving to Gulgong, in the central west of New South Wales, to raise miniature horses with her boyfriend. Her illness was a legacy of her years of addiction, and Wendy felt a terrible guilt about her own part in Lisa's death.

After her conversation with Fraser, Wendy came to the conclusion that the mysterious appearance of Lisa's face on Joy's statue was Lisa's way of saying: 'It's OK Mum'. ${ }^{25}$ For Wendy, Joy became a genuine memorial, a true place of the heart that offered both a focus for her grief and an avenue for reconciliation with her guilt. As Fraser relates, Wendy 'became the protector of JOY. When a drunk took off her head Wendy retrieved it for me to replace. ${ }^{26}$

Other responses were less violent but more enduring in their hostility. 'People attacked her physically and verbally'. A group of residents protested that there were no prostitutes in the area any more and that Joy's presence lowered the standard of the neighbourhood. 'We find it offensive to the eye', complained Ms 
Wendy Littlewood, a long-term resident of Yurong Street. 'It has caused great concern and a lot of embarrassment for people who live and work around here. ${ }^{27}$ Her protests were joined by the thirty residents of a nearby retirement home who petitioned the Council to have the statue removed. One elderly gentleman suggested: 'We should put up statues to returned soldiers - worthwhile people.' Another elderly male resident objected to the statue because it reminded people of the area's seedier recent history: 'Everybody knows it happened, but who wants to be reminded of it? ${ }^{28}$

According to the Wentworth Courier, 'most locals said that while one should not ignore the area's past it was another thing entirely to erect a monument honouring it.' Most also maintained its location was highly inappropriate - directly adjacent to Vincentian Village, a St Vincent de Paul crisis facility for both the aged and single homeless women. Paul Cook, the village's site manager, is quoted as saying that the sculpture 'upset' the elderly residents but was taken especially badly by those staying in the homeless women's shelter. 'A number of them', he said, 'have that background and want to escape it. The last thing they want to do is be reminded of it.' The Vincentian Newsletter carried a poem encapsulating the sentiments of residents:

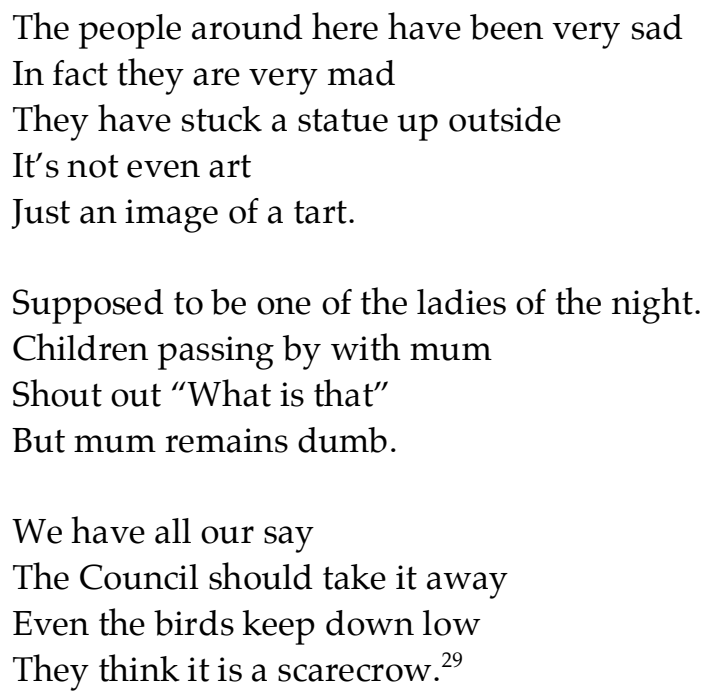

Others were more ambivalent. Susan, aged 57, worked at a nearby hospital. She thought the statue a 'terrific' piece of art but had reservations about the message it sent, given the health industry's attempts to get women off alcohol and cigarettes and out of 
prostitution. ${ }^{30}$ The fact that Joy was holding a cigarette didn't increase her popularity with the health conscious. However, Loui Fraser recalled that:

\begin{abstract}
Other people loved her, while repairing her on site I never got over how many times tourists, residents, taxi drivers, prostitutes, gay guys, restaurant owners etc would tell me how great they thought she was. A teacher from Sydney Grammar brought his students down, buses used to stop at the corner to show visitors. People offered me money to have her cast in bronze and have her there indefinitely. She was dressed up in feather boas and Christmas decorations. ${ }^{31}$
\end{abstract}

Perhaps her most ardent admirers were women attached to the Sex Workers' Outreach Project or SWOP. As Fraser recalls, 'I think I was

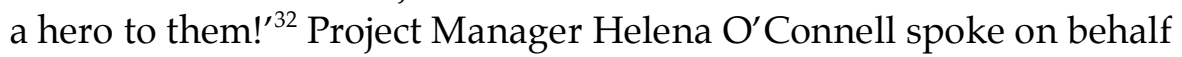
of SWOP: 'We think it's fantastic. Usually any publicity about street sex workers is negative, but this is positive and acknowledges their existence and that they can have a tough time. ${ }^{\prime 33}$

According to the SWOP bulletin, The Professional, Fraser had succeeded in her aim to portray a woman who combines dignity and femininity. ${ }^{34}$ The workers from SWOP would have bought Joy and installed her at SWOP headquarters had they had the funds or space. Instead, with wings attached, Joy's image adorned the SWOP Christmas cards. Her silhouette also appeared in the columns of The Professional.

While SWOP clearly had a vested interest in Joy, other commentators were more detached. Many wrote letters to the newspapers defending the sculpture on artistic grounds. Anna Cohn, past president of the Sculptors Society of New South Wales, though it 'a well-executed and interesting piece of artwork' that added interest to the city's dull corners. Victoria Ryan welcomed the challenge Joy posed to residents to come to terms with 'forgotten cultural histories' and 'confront the issues represented rather than suppressing them with moral indignation and reactionary iconoclasm.' Similarly, Patience Devas thought the statue a 'gentle reminder of one of the activities of this part of Sydney, rendered in a quiet and restrained manner.' In her view, 'only those who are bigoted or blinkered can take any exception to this depiction of life as it really is. ${ }^{, 35}$ 
Younger residents, according to the media coverage, tended to be more impressed than the older generation, commenting on the honesty of the statue itself in reflecting an ongoing reality of the area's social and economic life. A young mother brought her sevenyear-old daughter to see Joy as part of a day's outing to the Australian Museum. She told a journalist that she welcomed the statue because it departed from the hypocrisy which characterised so many of society's attitudes to sex. In her view, unlike the many socalled 'respectable' and well-heeled women who had sex with husbands they did not love in order to maintain a certain lifestyle, prostitutes were at least honest about what they were doing and were no less deserving of respect. ${ }^{36}$

In the short term, Joy's supporters prevailed. The Council rejected a petition from 141 residents to have her removed to a 'more appropriate location'. Deputy Mayor Christine Harcourt defended the decision, saying that the statue reflected the history of the area and was therefore appropriately located. ${ }^{37}$ In the longer term, however, her detractors triumphed. In the following year the statue was vandalised on a number of occasions. Several times the hand holding the cigarette was amputated while in the worst attack Joy's head was dislodged. ${ }^{38}$

On each occasion Fraser repaired the damage, although she eventually decided to remove the cigarette and fold the arms to make her less of a target. She could not, however, do anything about the 'continued pressure' on South Sydney Council which decided not to extend Joy's permit to loiter beyond the originally agreed exhibition period of twelve months. ${ }^{39}$ This was despite calls from Leo Schofield and others for the statue to be cast in bronze and made a permanent fixture. ${ }^{40}$

What was to become of Joy? Humphrey McQueen asked Fraser to lend the sculpture to an exhibition called 'Typically? Australian' he was curating for the Brisbane City Gallery. The exhibition investigated 'how design, in its manifestations ranging from fine art to popular culture, has affected and contributed to a sense of national identity' ${ }^{41}$ But the logistics of transporting and installing the statue prevented Joy from being included in this exhibition.

Fraser invited offers from private art collectors but decided to decline an invitation from the CEO of Telstra's Internet department to install Joy on the rooftop of his Sydney office. Instead, she 
approached the curator of Macquarie University's Sculpture Park who was enthusiastic about the idea of Joy relocating to North Ryde. The move was also supported by the Women's Room and the Women's Department of the University's Student Council and Joy made her way to her permanent home in April 1997. There she leads a more peaceful, if duller life. ${ }^{42}$

\section{SHIFTING GROUND: RECONCEPTUALISING PROSTITUTION}

The story of Joy and the controversy she sparked highlights some key issues in relation to the history of prostitution in Australia, particularly in Sydney. Loui Fraser's decision to do a sculpture of a streetwalker in itself is indicative of the sea change that had occurred in attitudes towards prostitution in the previous thirty years.

Influenced by new analyses emerging from the revived women's movement of the 1960s, many Australian feminists revised their views of prostitution and prostitutes. Whereas the so-called 'first wave' of feminists had seen prostitution almost exclusively in terms of female oppression at the hands of the sexual double standard, this new generation also took a more active interest in prostitutes as workers rather than victims.

This was especially the case in Australia where some women's liberation groups sought alliances with sex workers to improve the conditions under which they worked and their status in society. ${ }^{43}$ This signalled a new era of activism around issues of sex workers' rights which has resulted in legislative and attitudinal changes, at least in some areas. Most notably, New South Wales became the first jurisdiction in the Western world to decriminalise street prostitution. ${ }^{44}$ Despite other moves to decriminalise and legalise prostitution, New South Wales remains the only Australian State or Territory where some form of street soliciting is legal. ${ }^{45}$

The statue of Joy is both a product and a symbol of these changes. Sculptor Loui Fraser was one of many Australians who saw prostitutes as people rather than pariahs. 'Joy is supposed to be subtle', explained Fraser, 'a nice person with a personality. ${ }^{46}$ Fraser also adopted the analysis of prostitution as sex work rather than violence against women: 'This isn't a job that degrades women at all. I think it's just a job they do; this is work and they are businesswomen.' $^{47}$

Fraser's attitude also incorporated the common feminist position that prostitution was on a continuum with marriage. To quote her: 
I also believe, from living in St Ives for 20 yrs., that there are many, many women living on the North Shore who prostitute themselves within unhappy marriages, only they don't have sex with their husbands for money as such, they do it for "the swimming pool" or "the renovation" or to send their kids to Private Schools, they play the game but they are not as honest about it as the working women of East Sydney. ${ }^{48}$

It is hardly surprising that Loui Fraser became something of a hero to sex workers.

We also see elements of these views amongst the members of South Sydney Council who were open to both new ways of representing sex work and new ways of managing it. The Council that approved the statue was dominated by Australian Labor Party (ALP) members, reflecting a longstanding reformist agenda on the issue of prostitution in the ALP. It was, after all, an ALP Government under Neville Wran that decriminalised street prostitution in 1979. While feminist pressure was certainly important in the ALP's position, concern about civil liberties and police corruption also played a part. ${ }^{49}$ Recognising and acknowledging Sydney's prostitution history was one way of raising awareness of these ongoing issues.

As we have seen, many locals and visitors embraced Joy as a part of Sydney society. The difference in attitudes according to age was quite marked, although not a determinant. Some older residents were also appreciative of Joy's presence. And many who feared that she would attract an undesirable element to the area were subsequently pleased to discover that in fact she was a tourist drawcard, with busloads of visitors stopping to take photos and taxi drivers being directed to detour to pay her a visit. Local businesses were the beneficiaries. $^{50}$

If we reflect on the opposition expressed about Joy, we also see an interesting common theme. While a few people clearly continued to have strong moral objections both to prostitution and prostitutes, others were less easily categorised. According to their own statements, they recognised the history of their suburb and were glad that, for the most part, street prostitution no longer played such a prominent role, no doubt because of the greater availability of legal 
sex work in Sydney's brothels following recent law reform. The area was being transformed along with its property values.

And while many were accepting, if not approving, of sex workers and their right to work, they drew the line at celebrating the occupation which was clearly the way sex workers (and SWOP) saw the meaning of Joy. Joy did what good public art arguably should do: she forced people to confront issues that might otherwise have remained submerged. In doing so, she uncovered the limits of tolerance in a Sydney inner-city community that had lived with prostitution in its midst for most of its history.

\section{ENDNOTES}

${ }^{1}$ Tim Hall, 'Art and Urban Change: Public art in urban regeneration', in Alison Blunt, Pyrs Gruffudd, Jon May, Miles Ogborn and David Pinder (eds), Cultural Geography in Practice, Edward Arnold, London, 2003, p223.

2 Adrienne L. Burk, 'Beneath and before: continuums of publicness in public art', in Social \& Cultural Geography, vol 7, no 6, December 2006, p949.

3 Patricia Phillips, 'Out of Order: The Public Art Machine', (Artforum, December 1988) reprinted in Malcolm Miles, Tim Hall with Iain Borden (eds), The City Cultures Reader, second edition, Routledge, London, 2004, p191.

${ }^{4}$ Hall, 'Art and Urban Change', pp227-8.

5 ibid.

${ }^{6}$ Burk, 'Beneath and before', p949. See also Joanne Sharp, 'The life and death of five spaces: public art and community regeneration in Glasgow', in Cultural Geographies, vol 14, no 2, April 2007, pp274-292.

7 Annette Hamilton, 'Monuments and Memory', in Continuum: The Australian Journal of Media \& Culture, vol 3, no 1, 1990; Ken Inglis, Sacred Places: War Memorials in the Australian Landscape, Melbourne University Press, Carlton, 2001.

${ }^{8}$ See discussion on the controversial Another View Walking Trail in Melbourne in Jane Jacobs, 'Resisting reconciliation: the secret geographies of (post)colonial Australia', in Steve Pile and Michael Keith (eds), Geographies of Resistance, Routledge, London, 1997, pp203-18. Jacobs notes that while the sites on the Walking Trail provide 'another view', it is the artworks that were not permitted to be constructed, which are the more telling: see p214.

${ }^{9}$ A recent example of memorials to workers is the 'Memory Lines' sculpture by Ingrid Skirka at Darling Harbour, New South Wales, commemorating lives lost in workplace accidents. For a discussion on memorials to workers see Chilla Bulbeck, 'Building the Nation: Silences and Marginalities Concerning the Representation of Workers in Monuments', Labour History, no 59, 1990, pp16-27. Also, 'Aborigines, Memorials and the History of the Frontier', Historical Studies, vol 25, no 96, 1991, pp168-78; 'Australian History Set in Concrete? The Influence of the New Histories on Australian Memorial Construction', Journal of Australian Studies, no 28, 1991, pp3-16; and 'Women of Substance: the depiction of women in Australian monuments', Hecate, vol 18, no 2, October 1992, pp8-22.

${ }^{10}$ Chilla Bulbeck, 'Building the Nation', pp 18; 20. 
${ }^{11}$ While there are numerous critiques of 'New genre public art', this article takes from Miles an understanding of the form as 'process-based, frequently ephemeral, often related to local rather than global narratives, and politicised'. Malcolm Miles, Art, Space and the City: public art and urban futures, Routledge, London, 1997, p164. As such it is the 'counter-hegemonic', rather than activist nature of new genre public art, to which we refer. On the latter see, for example, Suzanne Lacy (ed), Mapping the Terrain: New Genre Public Art, Bay Press, Seattle, 1995.

${ }^{12}$ Hall, 'Art and Urban Change', p222.

${ }^{13}$ This account is based on Loui Fraser's unpublished manuscript, 'Joy's Story'. See also Sydney Morning Herald, 18 November 1995; Wentworth Courier, 22

November 1995. We are extremely grateful to Loui Fraser for sharing her manuscript and related copies of press clippings and other documents with us.

${ }^{14}$ Fraser, 'Joy's Story', p2.

${ }^{15}$ ibid, p1.

${ }^{16}$ South Sydney City Council (hereafter SSCC), Media Release, 3 November 1995.

17 ibid, p2.

18 ibid.

${ }^{19} \mathrm{H}$. Lefebvre, Writings on Cities, selected, translated and introduced by E. Kofman and E. Lebas, Blackwell Publishers, Cambridge, MA, 1996.

${ }^{20}$ Tim Hall,'Images of Industry in the Postindustrial City: Raymond Mason and Birmingham', Cultural Geographies, vol 4, no 1, January 1997, p58.

${ }^{21}$ For a history of prostitution see Raelene Frances, Selling Sex: a hidden history of prostitution, UNSW Press, Sydney, 2007. See also Roberta Perkins, Being a prostitute: prostitute women and prostitute men, George Allen and Unwin, Sydney, 1985; Roberta Perkins, Working Girls: Prostitutes, their Life and Social Control, Australian Institute of Criminology, Canberra, 1991; Roberta Perkins, 'An oral history of sex workers in Sydney', in Roberta Perkins, Garrett Prestage, Rachel Sharp and Frances Lovejoy (eds), Sex Work and Sex Workers in Australia, UNSW Press, Sydney, 1994.

${ }^{22}$ Hall, 'Art and Urban Change', p226.

${ }^{23}$ Jonathan I. Leib, 'Separate times, shared spaces: Arthur Ashe, Monument Avenue and the politics of Richmond, Virginia's symbolic landscape', Cultural Geographies, vol 9, no 3, 2002, p289.

${ }^{24}$ See for example, J. Bodnar, Remaking America: public memory, commemoration, and patriotism in the twentieth century, Princeton University Press, Princeton, NJ, 1992 and D. Haydon, The power of place: urban landscape as public history, MIT Press, Cambridge MA, 1995, cited in Jonathan I. Leib, 'Separate times, shared spaces', p290.

${ }^{25}$ ibid, p8.

${ }^{26}$ ibid.

27 'Joy to the world, and the world isn't happy', Sydney Morning Herald, 10 November 1995.

${ }^{28}$ Video interviews conducted by Lisa Molloy, 17 May 1996. The Wentworth Courier reported that two petitions calling for Joy's removal containing a total of 141 signatures were presented to a SSCC meeting in November. Wentworth Courier, 22 November 1995.

${ }^{29}$ The Village Green, April 1996.

30 'Local views mixed on sculpture', Wentworth Courier, 15 November 1995.

${ }^{31}$ Fraser, op cit, p8. 


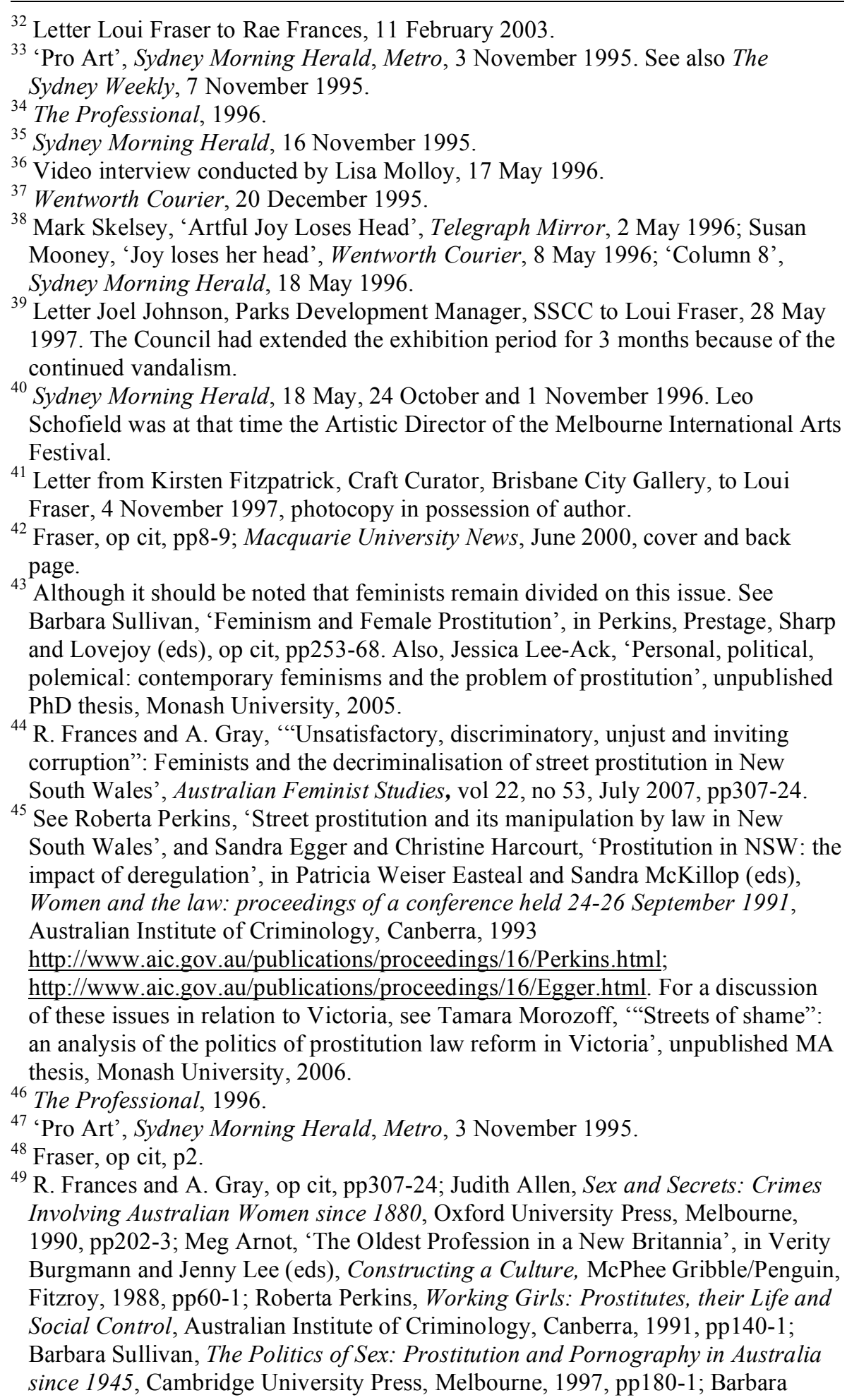


Sullivan, 'The women's movement and prostitution politics in Australia', in Joyce Outshoorn (ed), The Politics of Prostitution: Women's Movements, Democratic States and the Globalisation of Sex Commerce, Cambridge University Press, Cambridge, 2004, pp21-9; Marcia Neave, 'Prostitution Laws in Australia: Past History and Current Trends', in Perkins, Prestage, Sharp and Lovejoy (eds), op cit, pp78-9.

${ }^{50}$ Fraser, op cit, $\mathrm{p} 8$. 